\title{
C282Y and H63D mutation frequencies in a population from central Spain
}

\author{
S. Alvarez ${ }^{\text {a }}$, M.S. Mesa ${ }^{\text {b }}$,F. Bandrés ${ }^{\mathrm{a}}$ and \\ E. Arroyo ${ }^{\mathrm{a}, *}$

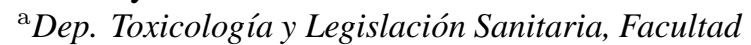 \\ de Medicina, Universidad Complutense de Madrid, \\ 28040-Madrid, Spain \\ ${ }^{\mathrm{b}}$ Sección de Antropología, Dep. Biología Animal I, \\ Facultad de Ciencias Biológicas, Universidad \\ Complutense de Madrid, 28040-Madrid, Spain
}

Objectives: To determine the frequency of hereditary hemochromatosis gene mutations, C282Y and H63D, from 125 autochthonous blood donors originating from a Central region of Spain, to provide epidemiological data about HFE gene in the Iberian Peninsula.

Methods: DNA extracted from blood samples was analyzed by PCR-RFLP. Restriction enzimes were Snab I and Bcl I for C282Y and H63D, respectively. Results were visualized with Ethidium Bromide staining after gel electrophoresis.

Results and discussion: $\mathrm{C} 282 \mathrm{Y}$ frequency was 0.02 and that of H63D was 0.16. Result for C282Y mutation falls within the range of variation of the Mediterranean populations. H63D frequency agrees with those reported for other European populations. In both cases frequencies obtained are the lowest of compared Spanish data.

Conclusions: This study is useful to compare expected versus presented C282Y and H63D frequencies in Spanish populations and to contribute to the knowledge of Spanish variability, rarely analyzed until now for HFE gene mutations.

\section{Introduction}

Hereditary hemochromatosis is an autosomal recessive disease affecting approximately 1/300 individuals of European origin [1]. This disorder causes overabsorption of iron from the intestine, increasing body iron overload. Progressive accumulation of iron appears on

\footnotetext{
*Correspondence address: Eduardo Arroyo, Dep. Toxicología y Legislación Sanitaria, Facultad de Medicina, Universidad Complutense de Madrid, 28040-Madrid, Spain. Tel.: +34 91 3941576; Fax: +34 91 3941606; E-mail: eduardoa@eucmax.sim.ucm.es.
}

different tissues and liver, joints, skin, heart and other organs may be affected which determine endocrine abnormalities, cirrhosis, arthropaty, cardiomyopathy, etc, and may be fatal if treatment is not applied. In 1976, Simon et al. reported an association of hemochromatosis with HLA loci [2]. Later, the hemochromatosis gene, named HFE, was identified on the short arm of chromosome 6 about 4, 5 megabases telomeric to HLAA [3]. HLA-linked hemochromatosis gene has heretofore been described exclusively in people of European ancestry. It is important to consider that there are other iron metabolism disorders different from this hereditary hemochromatosis, such as juvenile hemochromatosis, African iron overload or hereditary hyperferritinaemia, all of which are determined by other loci different from HFE [4]. The characterization of HFE gene has shown that it presents a mutation, named $\mathrm{C} 282 \mathrm{Y}$, found in most patients suffering hemochromatosis. This mutation is a $\mathrm{G} \rightarrow$ A transition at nucleotide 845 of the open reading frame that results in a $282 \mathrm{Cys} \rightarrow$ Tyr substitution in the protein product. Homozygosity for the $\mathrm{C} 282 \mathrm{Y}$ variant is closely associated with hemochromatosis, and its frequency is: $64-94.7 \%$ of European hemochromatosis patients $[3,5]$, although it has been reported in Australia (from individuals of European origin) that $100 \%$ of hemochromatosis patients are homocigotic for the $\mathrm{C} 282 \mathrm{Y}$ mutation [6]. A few other mutations related to hemochromatosis have been described in the HFE gene [7,8], the most important, considering its frequency, is H63D which corresponds to the transition $\mathrm{C} \rightarrow \mathrm{G}$ at nucleotide 187 resulting in a $63 \mathrm{His}$ $\rightarrow$ Asp substitution in the protein chain. The role of this second variant in causing genetic hemochromatosis is less clear in comparison with C282Y. However, hemochromatosis disease is shown in cases in which H63D and C282Y are present together in the same individual $[3,9]$. The allelic association between HLA$\mathrm{A}^{*} 03$ and hemochromatosis is well recognized [2,10]. Edwards et al. [11] demonstrated that approximately $70 \%$ of hemochromatosis patients possess at least one HLA-A*03. A possible origin of the mutation on a chromosome bearing an HLA-A*03 allele has been 
suggested [12]. Recent findings support the hypothesis that the mutation appeared in a relatively recent period (60-70 generations ago) on a *A3 *B7 haplogroup [10]. In addition, the finding of HLA alleles other than *A3 associated with hemochromatosis may be explained by recombination systems, which occurred as infrequent events, between these loci over many generations; another explanation could be the appearance of infrequent hemochromatosis causing mutations other than the two mentioned above.

The aim of this study is to establish population frequencies of C282Y and H63D mutations from a sample of Central Spain to provide epidemiological data which may permit us to relate both the incidence of hereditary hemochromatosis and presence of these two major mutations. This is the first report of mutation frequencies for the Central Spanish population. This contribution adds to our knowledge concerning European population and HFE markers.

\section{Material and methods}

\subsection{Sample}

DNA samples were obtained from 125 unrelated individuals. These individuals were blood donors and autochthonous (4 grandparents born in the studied region) from Central Spain (Vera-Jerte Valley, Cáceres province). This population was chosen because of the genetic resemblance to the majority of Spanish populations as shown in previous studies of STR variability and other markers $[13,14]$.

\subsection{Amplification protocol}

A $25 \mu$ l reaction mix containing 20 pmol of each primer, $75 \mathrm{mM}$ Tris $\mathrm{HCl}\left(\mathrm{pH} \mathrm{9.0),} 1.5 \mathrm{mM} \mathrm{MgCl}_{2}\right.$, $50 \mathrm{mM} \mathrm{KCl}, 20 \mathrm{mM}\left(\mathrm{NH}_{4}\right) \mathrm{SO}_{4}, 200 \mu \mathrm{M}$ each dNTP and $1 \mathrm{U}$ Taq polymerase (Biotools). PCR program was carried out in a Omn-E Thermal Cycler (Hybaid, $\mathrm{UK})$ for 1 cycle $\left(95^{\circ} \mathrm{C} 120 \mathrm{~s}\right)$ of initial denaturation, 35 cycles of amplification $\left(95^{\circ} \mathrm{C} 60 \mathrm{~s}, 55^{\circ} \mathrm{C} 30 \mathrm{~s}, 72^{\circ} \mathrm{C}\right.$ $60 \mathrm{~s})$ and 1 cycle of final extension $\left(72^{\circ} \mathrm{C} 60 \mathrm{~s}\right)$. PCR primers for detection of $\mathrm{H} 63 \mathrm{D}$ and $\mathrm{C} 282 \mathrm{Y}$ mutations were used according to Beutler et al. [15].

\subsection{RFLP assay}

$10 \mu \mathrm{l}$ of each final product were digested with $\mathrm{Bcl}$ I for H63D and Snab I for C282Y (New England Biolabs) at $50^{\circ} \mathrm{C}$ and $37^{\circ} \mathrm{C}$, respectively, overnight, according to manufacturer's protocol. Fragment polymorphism was separated by electrophoresis in 2\% Agarose gels and visualized with Ethidium Bromide.

\section{Results and conclusion}

125 blood samples were analyzed and the $\mathrm{C} 282 \mathrm{Y}$ and $\mathrm{H} 63 \mathrm{D}$ variants were identified. In relation to $\mathrm{C} 282 \mathrm{Y}$ mutation, five of the donors were $\mathrm{C} 282 \mathrm{Y}$ heterozygous and the rest carried the normal allele. No C282Y homozygous was detected. These results correspond to a C282Y gene frequency of $0.02 \pm 0.009$. The search for H63D mutation revealed that two individuals were H63D homozygous and 36 heterozygous while 87 exhibited normal alleles. H63D gene frequency was 0.16 \pm 0.023 .

For comparative purposes, Table 1 summarizes results from different European populations studied for HFE mutations. The C282Y mutation has been found in these populations, except Udmurts (USSR), Finland, Askenazi Jews, Cypriots and Turkey [4], but in these cases the number of characterized individuals is small and this fact may influence the absence of the mutation because of its low frequency. The relatively most elevated values were found in countries located in the Northern Europe: Denmark (9.5\% and 6.8\%) [4,16], United Kingdom (8\%-5.9\%) [4,17,18], Iceland (6.7\%) or Norway (6.4\%) [4]. The Mediterranean area presents lower values, between $0.5 \%$ in Italy [4] and $4.4 \%$ obtained in a region corresponding to Northern Spain (Cantabrians) [19]. Considering the Spanish population, to the present, only Northern Spain (Basques, Catalans and Cantabrians) $[4,19]$ is represented in the HFE gene studies; the rest of the Iberian Peninsula is unknown. In addition, two of the samples are composed of a reduced size of the phenotyped individuals. Our result for Central Spain, with a C282Y gene frequency of $2 \%$, falls within the range of variation of the Mediterranean populations and the lowest of compared Spanish data. H63D mutation is more widely distributed and its relationship with hemochromatosis is less clear. It is present in African, Asian and native American populations, although at a frequency lower than $2 \%$ in most of them. It is not found in most Australasians [4]. European populations show H63D fre- 
Table 1

Frequencies of H63D and C282Y mutations in European populations

\begin{tabular}{|c|c|c|c|c|}
\hline Population & $\mathrm{N}$ & H63D & $\mathrm{C} 282 \mathrm{Y}$ & Reference \\
\hline Iceland & 90 & 10.6 & 6.7 & [4] \\
\hline Norway & 94 & 11.2 & 6.4 & [4] \\
\hline USSR (Mekhelta) & 45 & 6.7 & 1.1 & [4] \\
\hline USSR (Udmurts) & 46 & 15.2 & 0 & [4] \\
\hline Finland & 38 & 11.8 & 0 & [4] \\
\hline The Netherland & 39 & 29.5 & 2.6 & [4] \\
\hline Denmark & 200 & 12.8 & 6.8 & [16] \\
\hline Denmark & 37 & 12.2 & 9.5 & {$[4]$} \\
\hline Germany & 53 & 18.9 & 1.9 & {$[4]$} \\
\hline Germany & 153 & 22.0 & 5.2 & [23] \\
\hline Germany (Bavarians) & 62 & 11.3 & 5.6 & [4] \\
\hline Austria & 271 & 13.0 & 3.7 & [24] \\
\hline United Kingdom & 368 & 12.1 & 6.0 & {$[4]$} \\
\hline United Kingdom (Wales) & 101 & 15.8 & 5.9 & [17] \\
\hline United Kingdom (NE Scotland) & 188 & 15.7 & 8.0 & [18] \\
\hline Ireland & 45 & 18.9 & 10.0 & [4] \\
\hline France ( Finistère) & 254 & 16.9 & 9.4 & [22] \\
\hline France (Rennes) & 139 & 16.5 & 2.9 & [20] \\
\hline France (Toulouse) & 95 & 15.8 & 4.2 & [21] \\
\hline Hungary & 277 & 12.3 & 5.6 & [25] \\
\hline Askenazi Jews & 35 & 8.6 & 0 & [4] \\
\hline Italy & 50 & 10.0 & 1.0 & [26] \\
\hline Italy & 91 & 12.6 & 0.5 & [4] \\
\hline Greece & 139 & 11.9 & 1.4 & [4] \\
\hline Greece (Cypriots) & 57 & 17.5 & 0 & [4] \\
\hline Turkey & 31 & 17.7 & 0 & [4] \\
\hline Turkey (Turks-Cypriots) & 39 & 10.3 & 0 & [4] \\
\hline Spain (Basques) & 28 & 30.4 & 3.6 & [4] \\
\hline Spain (Catalans) & 50 & 24.0 & 3.0 & [4] \\
\hline Spain (Cantabrians) & 213 & - & 4.4 & [19] \\
\hline Spain (Central region) & 125 & 16.0 & 2.0 & Present study \\
\hline
\end{tabular}

quencies greater than the other continents and is present in all studied samples with a variation range between $6.7 \%$, in a sample of Mekhelta from USSR, and 30.4\%, corresponding to the Spanish Basque sample [4]. The same authors summarized all studied individuals (1440) residing in European countries and obtained a general H63D frequency of $13.6 \%$. In contrast to $\mathrm{C} 282 \mathrm{Y} \mathrm{mu-}$ tation, H63D frequencies do not show any gradation from North to South, and Mediterranean people have a similar variation range in comparison with the north of Europe. The most elevated values are found in the Netherlands (29.5\%) and in the two analyzed series from Northern Spain: Basques (30.4\%) and Catalans (24.0\%) [4]. Our findings are consistent with this European variation for H63D; and the frequency for Central Spain $(16.0 \%)$ is lower than Northern Spanish samples but very similar to a great part of the other populations, such as France (15.8\%-16.9\%) [20-22], United King$\operatorname{dom}(12.1 \%-15.8 \%)[4,17,18]$ and Ireland $(18.9 \%)$ [4].

In conclusion, the results of this study present data concerning frequencies of HFE mutations related to hemochromatosis disease are useful to compare expected versus presented frequencies of individuals with hereditary hemochromatosis in the Spanish population. HFE mutations also show a high level of variability among populations, and this study provides an amplification of data about their distribution in European countries.

\section{Acknowledgements}

This work has been partially funded by multidisciplinar project from Complutense University PR182/96 no 6745 and DIGCYT project PB92-0224.

\section{References}

[1] C.Q. Edwards, L.M. Griffen, D. Goldgar, C. Drummond, M.H. Skolnick and J.P. Kushner, Prevalence of hemochromatosis among 11,065 presumably healthy blood donors, New Engl. J. Med. 318 (1988), 1355-1362.

[2] M. Simon, M. Bourel, M. Fauchet and B. Genetet, Association of HLA-A3 and HLA-B14 antigens with idiopathic hemochromatosis, Gut 17 (1976), 332-334. 
[3] J.N. Feder, A. Gnirke, W. Thomas, Z. Tsuchihashi, D.A Ruddy, A. Basava, F. Dormishian et al., A novel MHC class I-like gene is mutated in patients with hereditary haemochromatosis, Nat. Genet. 13 (1996), 399-408.

[4] A.T. Merryweather-Clarke, J.J. Pointon, J.D. Shearman and K.J. Robson, Global prevalence of putative haemochromatosis mutations, J. Med. Genet. 34 (1997), 275-278.

[5] B.R. Bacon, L.W. Powell, P.C. Adams, T.F. Kresina and J.H. Hoofnagle, Molecular medicine and hemochromatosis: at the crossroads, Gastroenterology 116 (1999), 193-207.

[6] E.C. Jazwinska, W.R. Pyper, M.J. Burt, J.L. Francis, S. Goldwurm, S.I. Webb, S.C. Lee, J.W. Halliday and L.W. Powell, Haplotype analysis in Australian hemochromatosis patients: Evidence for a predominant ancestral haplotype exclusively associated with hemochromatosis, Am. J. Hum. Genet. 56 (1995), 428-433.

[7] D.F. Wallace, J.S. Dooley and A.P. Walker, A novel mutation of HFE explains the classical phenotype of genetic hemochromatosis in a C282Y heterozygote, Gastroenterology 116 (1999), 1409-1412.

[8] V. Douabin, R. Moirand, A.M. Jouanolle, P. Brissot, J.Y. Le Gall, Y. Deugnier and V. David, Polymorphisms in the HFE Gene, Hum. Hered. 49 (1999), 21-26.

[9] G. Mercier, A. Burckel, C. Bathelier, E. Boillat and G. Lucotte, Mutation analysis of the HLA-H gene in French hemochromatosis patients, and genetic counseling in families, Genetic Counseling 9 (1998), 181-186.

[10] R.S. Ajioka, L.B. Jorde, J.R. Gruen, G. Yu, D. Dimitrova, J. Barrow, E. Radisky, C.Q. Edwards, L.M. Griffen and J.P. Kushner, Haplotype analysis of hemochromatosis: Evaluation of Different linkage-diseqilibrium approaches and evolution of disease chromosomes, Am. J. Hum. Genet. 60 (1997), 14391447.

[11] C.Q. Edwards, M.M. Dadone, M.H. Skolnick and J.P. Kushner, 1982, Hereditary hemochromatosis, Clin. Haematol. 11 (1982), 411-435

[12] M. Simon, L. LeMignon, M. Fauchet, J. Yaouang, V. David, G. Edan and M. Bourel, A study of 609 haplotypes marking for the hemochromatosis gene: (1) mapping of the gene near the HLA-A locus and characters required to define a heterozygous population and (2) hypothesis concerning the underlying cause of hemochromatosis-HLA association, Am. J. Hum. Genet. 41 (1987), 89-105.

[13] M.A. Ocaña, E. Arroyo-Pardo, C. Martínez-Labarga, M. Arroyo, V. Fuster and M.S. Mesa, Análisis de polimorfismos de STR en una región del Centro de España (Vera-Jerte, Cáceres), in: Investigaciones en Biodiversidad Humana, T.A. Varela, ed., Santiago de Compostela University, Santiago de Compostela, 2000, pp. 788-797.

[14] M.S. Mesa, J. Martín, V. Fuster, R. Fisac, Blood polymorphisms and Geography in the Sierra de Gredos, Spain, Hum. Biol. 66 (1994), 1005-1019.

[15] J.G. Beutler, T. Gelbart, C. West, P. Lee, M. Adams, R. Blackstone, P. Pockros, M. Kosty, C.P. Venditti, P.D. Phatak, N.K.
Seese, K.A. Chorney, A.E.T. Elshof, G.S. Gerhard and M. Chorney, Mutation analysis in hereditary hemochromatosis, Blood Cells, Mol. and Dis. 22 (1996), 187-194.

[16] R. Steffensen, K. Varming and C. Jersild, Determination of gene frequencies for two common haemochromatosis mutations in the Danish population by a novel polymerase chain reaction with sequence-specific primers, Tissue Antigens 52 (1998), 230-235.

[17] A.G. Roberts, S.D. Whatley, R.R. Morgan, M. Worwood and G.H. Elder, Increased frequency of hemochromatosis Cys282Tyr mutation in sporadic porphirya cutanea tarda, Lancet 349 (1997), 321-323.

[18] Z. Miedzybrodzka, S. Loughlin, D. Baty, A. Terron, K. Kelly, J. Dean, M. Greaves, M. Pippard and N. Haites, Haemochromatosis mutations in North-East Scotland, Br. J. Haematol. 106 (1999), 385-387.

[19] E. Fábrega, B. Castro, L. Sánchez-Castro, A. Benito, J.L. Fernández-Luna, F. Pons-Romero, Prevalencia de la mutación Cys282Tyr del gen de la hemocromatosis en Cantabria y en los pacientes diagnosticados de hemocromatosis hereditaria, Med. Clin. (Barc.) 112 (1999), 451-453.

[20] A.M. Jouanolle, G. Gandon, P. Jézéquel, M. Blayau, M.L. Campion, J. Mosser, P. Fergelot, B. Chauvel, P. Bouric, G. Carn, N. Andrieux, I. Gicquel, J.Y. Le Gall and V. David, Haemochromatosis and HLA-H, Nat. Genet. 14 (1996), 251252.

[21] N. Borot, M.P. Roth, L. Malfroy, C. Demangel, J.P. Vinel, J.P. Pascal and H. Coppin, Mutations in the MCH class Ilike candidate gene for hemochromatosis in Frech patients, Inmunogenetics 45 (1997), 320-324.

[22] P. Jézéquel, M. Bargain, F. Lellouche and F. Geffroy, Allele frequencies of hereditary hemochromatosis gene mutations in a local population of west Brittany, Hum. Genet. 102 (1998), 332-333.

[23] R. Gottschalk, C. Seidl, T. Löffler, E. Seifried, D. Hoelzer and J.P. Kaltwasser, HFE codon 63/282 (H63D/C282Y) dimorphism in German patients with genetic hemochromatosis, Tissue Antigens 51 (1998), 270-275.

[24] C. Datz, M.R.A. Lalloz, W. Vogel, I. Graziadei, F. Hackl, G. Vautier, D.M. Layton, T. Maier-Dobersberger, P. Ferenci, E. Penner, F. Sandhofer, A. Bomford and B. Paulweber, Predominance of the HLA-H Cys282Tyr mutation in Austrian patients with genetic haemachromatosis, J. Hepatology 27 (1997), 773-779.

[25] A. Tordai, H. Andrikovics, L. Kalmar, M. Rajczy, B. Sarkadi, I. Klein and A. Varadi, High frequency of the haemochromatosis C282Y mutation in Hungary could argue against a Celtic origin of the mutation, J. Med. Genet. 35 (1998), 878-879.

[26] M. Carella, L. D'Ambrosio, A. Totaro, A. Grifa, M.A. Valentino, A. Piperno, D. Girelli, A. Roetto, B. Franco, P. Gasparini and C. Camaschella, Mutation analysis of the HLA-H gene in Italian hemochromatosis patients, Am. J. Hum. Genet. 60 (1997), 828-832. 


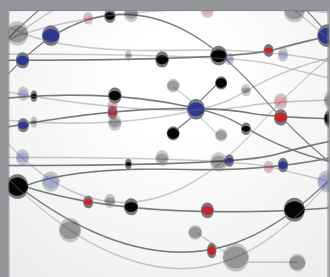

The Scientific World Journal
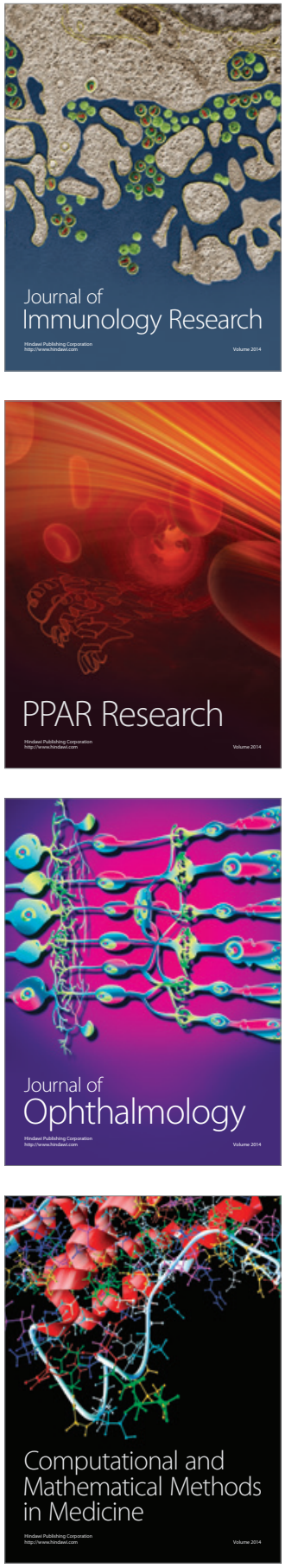

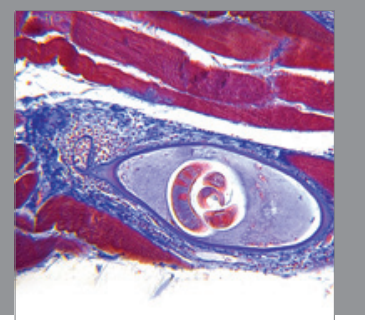

Gastroenterology

Research and Practice
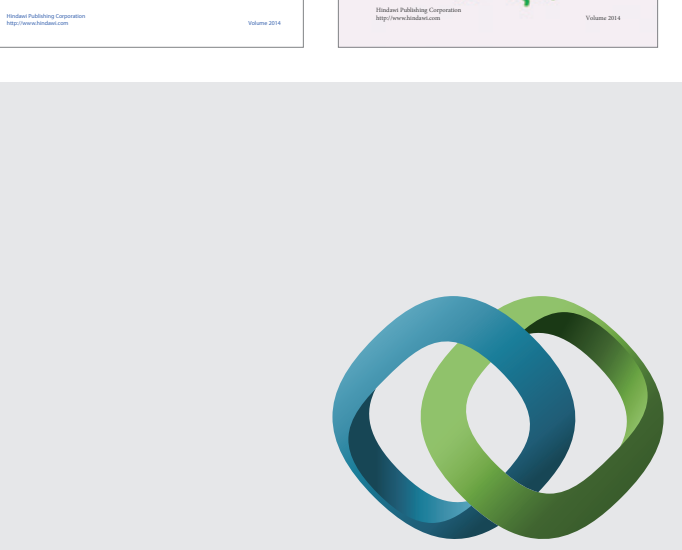

\section{Hindawi}

Submit your manuscripts at

http://www.hindawi.com
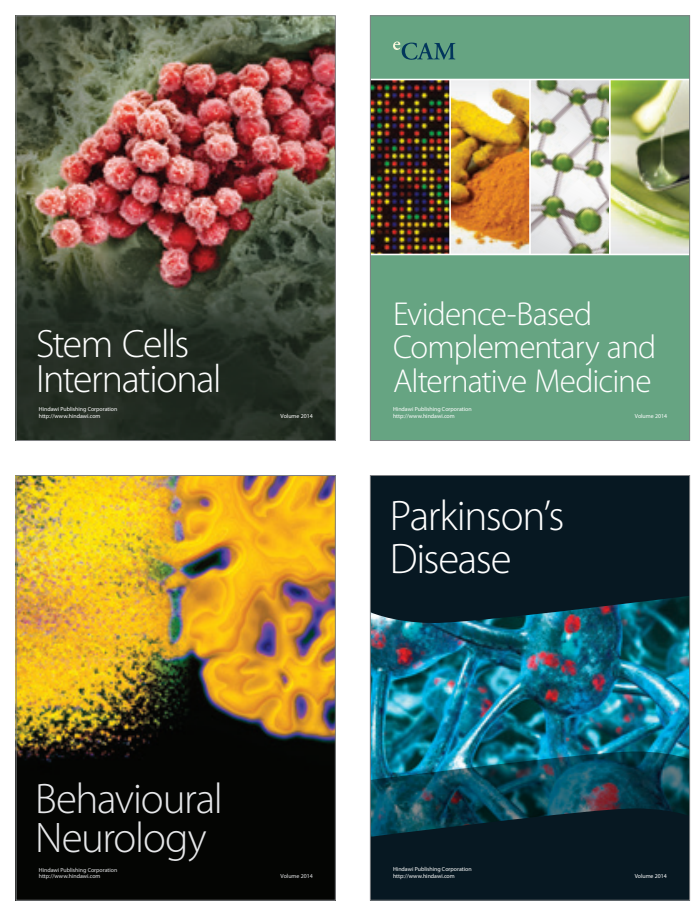

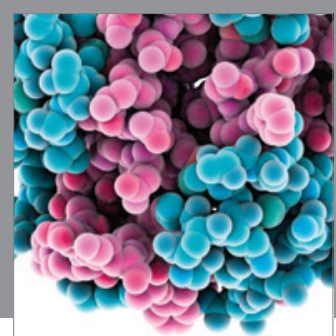

Journal of
Diabetes Research

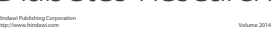

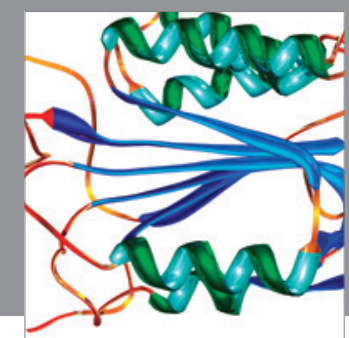

Disease Markers
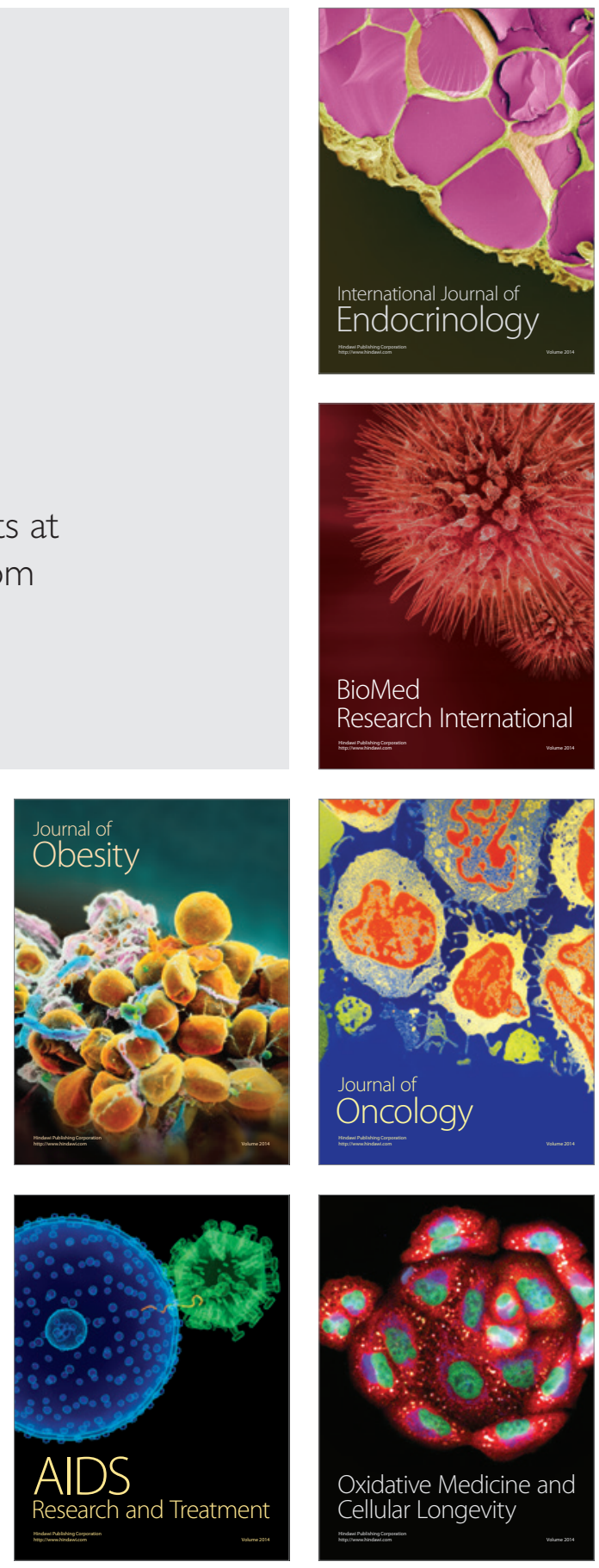